\title{
Psychoactive substances in Poland and Hungary - how to fight them (problem overview)?
}

\author{
PIOTR JóźWIAK \\ ORCID: 0000-0001-6223-971X \\ Department of Public Law and Theory of Law, Faculty of Psychology and Law, \\ SWPS University of Social Sciences and Humanities
}

\section{Introduction}

The first mention of intoxicants dates back to earlier than $7000 \mathrm{BC}$, when the description of crops and opium preparation was discovered on Sumerian tablets from that period. In ancient times taking drugs was usually related to religious or healing ceremonies. ${ }^{1}$ The first mention of hashish and opium can be found in ancient Egypt, China, India and Mesopotamia. In South America the most popular substance of this kind were coca leaves, which quickly spread to Western Europe. ${ }^{2}$

The appearance of opium in Europe even led to the so called opium wars between Britain and China, the first of which broke out in 1839. The

* This study is a changed English version of a speech given in English during an International Scientific Conference at Dunaújvaros University, Hungary, entitled East-West Cohesion (Dunaújvaros 11-12 November 2019). The conference focused on cohesion of policy between Eastern and Western Europe. One of the conference subjects was related to Safety and Security.

1 T. Srogosz, Prawo międzynarodowe i unijne wobec nielegalnego obrotu narkotykami, Częstochowa 2016, p. 25.

2 Ibid. 
increased use of drugs and the appearance of heroin have forced many countries to introduce the control of intoxicants. Undoubtedly, drugs became one of the plagues of the 20th century. ${ }^{3}$

Although the war on drugs is ongoing, surely it cannot be stated that it has been won. Over the last few years contemporary Europe has had to face a totally new phenomenon, namely substances commonly referred to as legal highs or designer drugs. These new substances are slowly pushing out 'traditional' drugs. Consequently, people dealing in these drugs are becoming more and more responsible for the illnesses and deaths of many people. Legal highs also have negative effects on the mental condition of individuals.

As far as the sources and origins of 'new drugs' are concerned, in the literature it is quite unanimously acknowledged that the first instances of selling intoxicants online without any legislative control were observed in New Zealand between 1999-2000. ${ }^{4}$ Then they were also considered a safe substitute for popular drugs. Since the very beginning the advantage of this type of substances over traditional drugs boiled down to the fact that their sale was, in principle, legal, especially when they first appeared in various countries. It was also believed that they were both safer and less costly. ${ }^{5}$ Therefore, they have gained huge popularity in both Europe and the USA. ${ }^{6}$

Initially, there were some attempts of self-regulation related to the use of legal highs, among others by creating 'a set of guidelines' on substances of this kind. Notwithstanding this however, the research has shown that drug users frequently overdosed the prescribed legal limit. ${ }^{7}$

\section{Ibid.}

4 D. Błachut, B. Szukalski, "Dopalacze — właściwości chemiczne, skala zagrożeń i przeciwdziałanie rozpowszechnianiu", Przegląd Bezpieczeństwa Wewnętrznego 2012, No. 6, p. 111.

5 P. Kurowska,“Dopalacze - jak walczyć z nowymi truciznami?”, Biuletyn Głównej Biblioteki Lekarskiej 2018, No. 2, p. 219.

${ }^{6}$ Cf. C. Wilkins, P. Sweetsur, "Differences in harm from legal BZP/TFMPP party pills between North Island and South Island users in New Zealand: A case of effective industry self-regulation", International Journal of Drug Policy 21, 2010, pp. 86-90.

7 Ibid. 


\section{It has been indicated in the literature that:}

Chemical compounds referred to as designer drugs (modified drugs) until being regulated by law, may be offered on the drug market without any legal sanctions. Furthermore, over the last few years it has been shown they may be sold in legally available products in stationary or online stores. Since their number is on the increase and new drugs are produced, a continuous monitoring of the global market with relation to new psychoactive drugs (NSP) is necessary. ${ }^{8}$

The most well-known and primary drug from this group is benzylpiperazine (BZP), which until the end of 2008 had been easily accessible online as a legal high. ${ }^{9}$ In the literature, it is indicated that in the 1970s BZP was examined as a potential antidepressant and the research proved that it had stimulating properties similar to those of amphetamine. In the 1980s Edyt, a pharmaceutical company in Hungary (since 1985 the company has been called EGIS - editorial note) used BZP to produce a chemical compound called EGYT-475 which was sold as an antidepressant called Trelibet. However, it was quickly withdrawn from the market due to its side effects (insomnia, agitation, abnormal heart rhythm, heart rhythm disturbances). During the metabolism process Trelibet changed to BZP, and probably owing to this modification, it can stimulate the central nervous system. Currently, BZP does not have any pharmaceutical or commercial applications, but it is used in small amounts in scientific research. ${ }^{10}$

Counteracting designer drugs trafficking is surely the area for domestic criminal law. However, in recent years, intensifying cross-border activity of gang organizations selling legal highs, opening the borders with the European Union or the Schengen area, as well as a massive transfer of designer drugs trafficking to the Internet (frequently a different country than the one to which they are sent) have led to increased significance of international cooperation, especially within the EU, in terms of illegal sales of designer drugs.

In 2013 the European Commission proposed a first comprehensive draft of regulations, which were to facilitate the EU's war on legal highs - new psychocative substances (NPS) used instead of illegal drugs such as cocaine and ecstasy. On the basis of these regulations proposed by the Com-

\footnotetext{
8 D. Błachut, B. Szukalski, op. cit., p. 112.

9 Ibid.

10 Ibid., p. 114 and literature thereof.
} 
mission, harmful psychoactive substances were to be quickly withdrawn from the market without affecting their legal use for industrial and trading purposes. The motion was prepared after the European Monitoring Centre for Drugs and Drug Addiction (EMCDDA) and Europol warnings about the scale of drug dealing, and after the publishing of the report of 2011 in which it was stated that the EU mechanism to counteract the problem of NPS required strengthening (IP/11/1236). ${ }^{11}$

In Europe there are several various methods of outlawing legal highs. The two most frequently applied new legal methods which have been in a way a response to the scale of psychoactive drugs trafficking are: generic and analog control measures. ${ }^{12}$ The traditional solution of delegalizing each substance separately proved to be ineffective, since it was too slow. Delegalization of each substance requires time and following a lengthy legal procedure. ${ }^{13}$ For instance, until 2013 banning one substance on the territory of the EU took approximately 2 years. ${ }^{14}$

Until 2018 in the Polish legal system banning a new psychoactive substance required an amendment of the Act on Prevention of Drug Abuse. Only in the initial period when the problem of legal highs appeared in Poland, delegalization was conducted yearly. In July 2015 introducing the control of 114 new psychoactive substances had been preceded by several years of research and previous delegalization took place in 2011 . $^{15}$

In case of generic control measures legislation includes a precise definition of a family of substances (particularly substituent groups in specified positions in the molecule). This type of legislation has been implemented, for instance in Hungary, Lithuania, Latvia, Ireland and Great Britain. ${ }^{16}$

Analog control measures rely on more the general definition of pharmacological effect and chemical structure of psychoactive substances and such a solution has been used for example in the USA. Therefore, while

11 European Commission press release of 17 September 2013, https://europa.eu/ rapid/press-release_IP-13-837_pl.htm (access: 31.10.2019).

12 A. Malczewski, M. Kidawa, Nowe substancje psychoaktywne w Europie. Skala zjawiska i przeciwdziałanie, Warszawa 2018, p. 27 and f.

13 Ibid.

14 European Commission press release of 17 September 2013.

15 A. Malczewski, M. Kidawa, op. cit., p. 27.

16 Ibid., p. 28. 
applying this method a group of substances with similar effects is delegalized. ${ }^{17}$

\section{Psychoactive substances in Poland and Hungary}

Hardly a week passes by without the media in Poland or Hungary reporting about deaths as a result of taking designer drugs.

'Invasion of legal highs in Budapest', 'New drug causes havoc', 'Deaths due to new dangerous substance on the increase', 'Police have detained dealer trafficking in new legal highs'. These were only some of the newspaper headlines in Hungary in 2017. ${ }^{18}$

Meanwhile, Rzeczpospolita published articles entitled: 'Tracking down designer drugs online', 'Designer drug dealer to be punished', 'Imprisonment for selling legal highs as supplements for sportspeople', '100 000 PLN penalty for designer drugs'.

The appearance of new substances with unknown chemical contents frequently causes mass poisoning, leading to deaths which are often widely reported in the media coverage. This is most frequently followed by radical law changes which are intended to facilitate counteracting legal highs.

A similar situation also occurred in Poland in the 1990s when stimulating substances containing additional amounts of, among others, cocaine, amphetamine or taurine were called 'legal highs'. This term often referred to various diet supplements and substances used to build muscles which were especially popular among bodybuilders. ${ }^{19}$

The first official shop (head shop) with so-called designer drugs was opened in 2008 in Łódź. ${ }^{20}$ In 2010 all over Poland there were already 1400 such head shops and selling online was on a massive scale. ${ }^{21}$

17 Ibid.

18 P. Sarosi, “The problem with drugs or exclusion?”, https://krytykapolityczna.pl/ narkopolityka/problem-z-narkotykami-czy-z-wykluczeniem/ (originally the text was published at politicalcritique.org. Translated by K. Byłow-Antkowiak) (access: 31.10.2019).

19 G. Zawadka, W. Wybranowski, "Dopalacze schodzą do podziemia", Rzeczpospolita, 5 October 2010.

20 Ibid.

21 P. Kurowska, op. cit., p. 219. 
In 2010 following numerous media reports on the negative effects of legal highs on the life and health of many individuals, the government introduced a ban on producing and marketing various substances commonly known as designer drugs. This ban was hedged, in principle, with an administrative sanction in the form of PLN 20,000 to PLN 1,000,000 fine. In order to stop the development of drug trafficking, administrative and legislative measures have been taken. Such measures are simple to apply and therefore effective in counteracting negative social and economic phenomena. Undoubtedly, until legal highs were traded in shops and other similar locations, that is institutions controlled by public administration, the choice of the measures was appropriate. However, relying on administrative and legislative means hindered the possibility of bringing designer drug dealers to justice. In 2010 the massive attack of police and sanitary services on the drug market was effective only for a short period of time. The number of head shops decreased, but online trafficking and trading under the cover of a different business activity soared dramatically (for instance selling barbecue lightwood or collector's items). In the following years there were attempts to amend the law and treat legal highs as other drugs, however, these trials were futile and failed.

Another major change took place in 2018 when, as a result of an amendment, many legal highs were, to put in simply, treated as traditional drugs. Such a move was justified and effective since it led to eliminating from Polish streets all legally-run head shops, which under the pretext of different business activity in reality dealt in designer drugs. Obviously, this does not mean that the problem disappeared completely, as trafficking in such substances was transferred to the Internet and onto the streets.

Therefore, it is clearly visible that since the amendment of 2018 the Polish model of counteracting legal highs has been based on generic control measures. It has already been highlighted that similar methods are applied in Hungary, the country which in 2018 along with a major part of Europe experienced an influx of new synthetic drugs which partly replaced ordinary illegal substances. ${ }^{22}$ Unlike other parts of Europe, where

22 The political transition that took place in Hungary forced the authorities to officially face new, negative phenomena, such as drug-related crimes. F. Nagy, Z. Szomora suggest: "After the political transition, Hungary had to face the drug problem for the first time. We do not have the opportunity to discuss the criminal legislation in the field of 
legal highs were used mostly among youngsters at parties, in Budapest they became widely used among heroin and amphetamine users who were put on the sidelines.

Until 2011 amphetamine had almost disappeared from the streets, as most drug addicts slowly began to take various designer drugs, such as 'Diablo' or 'Spice', colloquially referred to as 'magic tobacco'.

The inhabitants of many Hungarian cities sensed the financial potential related to selling these substances. One dose of magic tobacco cost 500 forints (\$1.8), significantly less than alcohol. Since legal highs undergo regular controls and are listed by the government as new psychoactive substances, their producers constantly change the contents and wait for new substances imported from Asia. ${ }^{23}$

In order to monitor new psychoactive substances in Hungary, in 2012 a government decree included their quick evaluation. It included NPSs in Minister for Human Capacities Decree No 55/2014, which means temporary monitoring over the period of one year with a possible extension to one year (or until new information is released). Consequently, the new section of the Criminal Code of 2013 prescribes three years of imprisonment for drug production and (since January 2014) between one and five years for trafficking, and up to three years for possessing more than a small amount of new psychoactive substances. The very definition of 'a small amount' has been reduced from $10 \mathrm{~g}$ to $2 \mathrm{~g}$ in 2017 . The section penalizing

drugs crimes in this study; we briefly refer to the fact that it followed the general tendencies of criminal legislation. These days, the provisions of the Criminal Code concerning drugs crimes are very severe, which is further supported by the Constitutional Court that has recently annulled some rules related to diversion possibilities". F. Nagy, Z. Szomora, "The Development of the Hungarian Criminal Law over the Past Twenty Years", [in:] The Transformation of the Hungarian Legal Order 1985-2005 Transition to the Rule of Law and Accession to the European Union, eds. A. Jakab, P. Takács, A.F. Tatham, Budapest-Liverpool 2007, p. 199. Initially in Hungary, especially in the 1990s, the main focus was on healing measures and means of punishment not involving loss of liberty, particularly toward drug addicts. See more: M. Lẻvay, "Changes in the Social Function of Criminal Law in Hungary from 1985 to 2005", [in:] ibid., p. 243. However, quite quickly the penal policy in this respect changed radically. In 1999 in the so-called set of Acts against organized crimes accepted by Victor Orban's government, new more severe penalties were introduced for drug-related crimes. L. Korinek, "Principles of Criminal Policy in Hungary", [in:] ibid., p. 254.

23 P. Sarosi, op. cit. 
the encouragement of youths to take 'substances or intoxicants, but not classified as a medicine' was retained, although the maximum penalty has been reduced from three to two years. ${ }^{24}$

Undoubtedly, the proposed solution is in line with the Hungarian policy of counteracting drugs, including legal highs, by using firstly the regulations of the criminal law. Already in 2004 the Hungarian Constitutional Tribunal acknowledged the key role of criminal law in limiting and counteracting this social problem. The Constitutional Court declared that even the most minor drug-related offense deserved criminalization and undoubtedly such a solution complies with the Hungarian Constitution. ${ }^{25}$

The analysis presented in this study, although mainly only signaling specific problems, has not only a theoretical but primarily practical role. The choice of Poland and Hungary is not random as both countries have one of the highest percentage intake of legal highs in Europe. In both countries possessing and trafficking in designer drugs is punishable by criminal liability, and the execution model of this liability is based on socalled generic law.

\section{Summary and conclusions}

This study pinpoints only some possible problems, but they require a more in-depth analysis in the literature. Conducting a more detailed comparative study including legal aspects is desired and undoubtedly justified because of the so-called nationality principle. It permits a country, for example Poland, to exercise its criminal jurisdiction over any of its nationals accused of criminal offenses in foreign state and also the jurisdiction of the country where the crime was committed. This situation requires so-called 'double criminality'. ${ }^{26}$ For instance, if a Polish citizen in a foreign country where it is legal, possesses, sells or takes psychoactive substances, after his return to Poland he cannot be punished for this crime.

24 A. Malczewski, M. Kidawa, op. cit., pp. 114-115.

25 See: M. Lẻvay, op. cit., p. 241, and there the judgment of the Hungarian Constitutional Tribunal of 13 December 2004.

26 L. Gardocki, Prawo karne, Warszawa 2019, pp. 43-43. See also: A.J. Szwarc, "Criminal law", [in:] Handbook of Polish Law, eds. W. Dajczak, A.J. Szwarc, P. Wiliński, Warszawa-Bielsko-Biała 2011, pp. 159-161. 
In a certain sense, to a very limited extent, there may be numerous instances when a Polish court will need to apply foreign law (for example Hungarian). Therefore, it is desired to record all comparative law analyses. This issue is especially far-reaching, if we consider the fact that legal highs trafficking is mostly on the Internet and illegal substances are dispatched from one country to another.

The fact that possessing designer drugs is punishable both in Poland and Hungary does not mean automatically the possibility of executing criminal liability. The doubts concern the possibility of calling a person to account if the list of legal highs shall vary significantly between Poland and Hungary. In this respect it needs to be verified if bringing a person to justice shall not violate the fundamental right to decide dubious circumstances for the benefit of the accused or the ban on using extended interpretation to the detriment of the accused.

As it is legitimately indicated in the literature, under the Polish Act on Prevention of Drug Abuse the possibility to apply the regulations of Polish criminal law to perpetrators committing a crime abroad is highly limited due to the descriptive technique. The Polish legislator used many references to other acts while describing various drug-related crimes. As D. Zając highlights, if a crime is committed abroad, in principle, the binding law shall be the foreign one, not Polish. ${ }^{27}$ Consequently, this may result in immense obstacles as for the possibility of bringing such a perpetrator to justice.

In the literature, it is stated that:

New psychoactive substances (designer drugs) constitute a challenge both for help and support programs i.e., prevention schemes, education, treatment and damages reduction, as well as for services involved in the reduction of supply both in Poland and Europe. It has been 10 years since NPS appeared in Poland and Europe on a wider scale. According to the European Monitoring Center for Drugs and Drug Addiction (EMCDDA) in 2014 a record number of 101 NPS was observed in Europe (EMCDDA 2015:16). A few years later, in 2017 the number decreased to 51 (EMCDDA 2018:32), but drug-related poisoning in Poland was still very high — approximately 4300 cases in 2017, and the year before 2016 as well. One reason for the lower number of new substances in Europe may be attributed to more effective legislative solutions introduced by many EU countries. These

27 D. Zając, [in:] Przestępstwa narkotykowe i dopalacze. Komentarz, eds. W. Górowski, D. Zając, Kraków 2019, p. 57. 
measures are aimed at delegalizing all groups of substances (generic controls) and monitoring all NPSs not included in the regulation (blanket ban). ${ }^{28}$

It has already been pinpointed in this study that counteracting legal highs is of interest among EU institutions. Currently, the document in force is the Directive (EU) 2017/2103 of the European Parliament and of the Council of 15 November 2017 amending Council Framework Decision 2004/757/JHA in order to include new psychoactive substances in the definition of 'drug' and repealing Council Decision 2005/387/JHA.

Despite introducing many far-reaching changes in the choice of methods and institutions engaged in fighting with legal highs, the government has never decided to involve local government units in this activity. Nevertheless, as everyday experience frequently demonstrates, local authorities suffer the negative effects of designer drugs to the greatest extent. The legislative and sometimes non-legislative methods presented in this report which are used by some local government units to counteract legal highs clearly show that they seek active participation in this fight. Nonetheless, in the current legislation system there are no legal grounds available to facilitate such activity.

Another significant problem that both Poland and Hungary need to face is synthetic cannabis, which is a mixture of chemical compounds with effects similar to that of real cannabis. Synthetic substitutes are sold, similarly to legal highs, as legal products in so-called 'smart shops'. According to last year's questionnaire of the Global Drug Survey, 13\% of respondents admitted to its use, which is the highest result among the 50 countries participating in the survey. Hungary - as second in the ranking — is far behind with slightly more than $5 \%$ of respondents admitting to using synthetic cannabis last year. ${ }^{29}$

\section{Bibliography}

Błachut D., Szukalski B., "Dopalacze - właściwości chemiczne, skala zagrożeń i przeciwdziałanie rozpowszechnianiu", Przegląd Bezpieczeństwa Wewnętrznego 2012, No. 6.

28 A. Malczewski, M. Kidawa, op. cit., p. 13.

29 As cited by: "Polacy na dopalaczach", https://www.newsweek.pl/polska/dopalacze-w-polsce-narkotyki-syntetyczne-konopie-uzaleznienie/e7pnhp8 (access: 31.10.2019). 
Gardocki L., Prawo karne, Warszawa 2019.

Korinek L., "Principles of criminal policy in Hungary", [in:] The Transformation of the Hungarian Legal Order 1985-2005 Transition to the Rule of Law and Accession to the European Union, eds. A. Jakab, P. Takács, A.F. Tatham, Budapest-Liverpool 2007. Kurowska P., "Dopalacze - jak walczyć z nowymi truciznami?", Biuletyn Głównej Biblioteki Lekarskiej 2018, No. 2.

Lẻvay M., "Changes in the social function of criminal law in Hungary from 1985 to 2005", [in:] The Transformation of the Hungarian Legal Order 1985-2005 Transition to the Rule of Law and Accession to the European Union, eds. A. Jakab, P. Takács, A.F. Tatham, Budapest-Liverpool 2007.

Nagy F., Szomora Z., "The development of the Hungarian criminal law over the past twenty years", [in:] The Transformation of the Hungarian Legal Order 1985-2005 Transition to the Rule of Law and Accession to the European Union, eds. A. Jakab, P. Takács, A.F. Tatham, Budapest-Liverpool 2007.

Malczewski A., Kidawa M., Nowe substancje psychoaktywne w Europie. Skala zjawiska i przeciwdziałanie, Warszawa 2018.

Przestęstwa narkotykowe i dopalacze. Komentarz, eds. W. Górowski, D. Zając, Kraków 2019.

Sarosi P., "The problem with drugs or exclusion?" (originally the text was published at politicalcritique.org. Translated by K. Byłow-Antkowiak), https://krytykapolityczna. $\mathrm{pl}$ /narkopolityka/problem-z-narkotykami-czy-z-wykluczeniem.

Srogosz T., Prawo międzynarodowe i unijne wobec nielegalnego obrotu narkotykami, Częstochowa 2016.

Szwarc A.J., "Criminal law”, [in:] Handbook of Polish Law, eds. W. Dajczak, A.J. Szwarc, P. Wiliński, Warszawa-Bielsko-Biała 2011.

Wilkins C., Sweetsur P., "Differences in harm from legal BZP/TFMPP party pills between North Island and South Island users in New Zealand: A case of effective industry self-regulation”, International Journal of Drug Policy 21, 2010, No. 21.

Zawadka G., Wybranowski W., "Dopalacze schodzą do podziemia", Rzeczpospolita, 5 October 2010.

\section{Summary}

In view of the very serious social problem of designer drugs, which is growing with every passing day, we must take resolute and effective action as quickly as possible. Undoubtedly, designer drugs have become one of the plagues of the 21 st century. The choice of Poland and Hungary is not random, as both countries have one of the highest percentage intakes of legal highs in Europe. In both countries possessing and trafficking in designer drugs is punishable by criminal liability.

Keywords: drugs, criminal law, designer drugs, psychoactive substances, crime. 